\title{
Experimental Studies on the Spatial Structure and Distribution of Flow Velocities in Bolt Fishways
}

\author{
Marta Puzdrowska ${ }^{1 *}$, Tomasz Heese ${ }^{1}$ \\ 1 Environmental and Geodetic Sciences, Faculty of Civil Engineering, Koszalin University of Technology, \\ ul. Śniadeckich 2, 75-453 Koszalin, Poland \\ * Corresponding author's e-mail: marta.puzdrowska@wp.pl
}

\begin{abstract}
One of more important elements affecting the efficiency of fish passes is a 3D spatial structure of the flow and the flow velocity. The paper presents an analysis pertaining to the deformations of these elements caused by the modification of the fishway's partition geometry. It has a crucial meaning for the ability of fish to migrate through the fish pass. The research has a key practical significance as it proves the way the apparent modification of the partition geometry affects the hydraulic conditions within the entire the channel of the fishway. It may have very serious consequences for the design assumptions. The presented results of the experimental research were obtained as a consequence of the site and laboratory tests carried outusing a physical model. The measurements were performedfor 3 components of flow's instantaneous speed within the indicated measurement sections. The results were developed using Matlab software. It was established that the number of whirls produced in the fishway's pool depends on the quantity of spillway slots and - what seems to have the greatest impact on the flow structure - on the location of slots. The size of whirls is determined by the geometry of spillway slots. The presence of additional spillway slots in the pool, except for the huge main migration slot, contributes to the generation of more whirl structures within the recirculation zone. The more whirls produced in each of the whirl zones, the smaller their diameter. Thisshould create more favourable conditions for the fish migration.
\end{abstract}

Keywords: turbulent flow, bolt fishway, design of bolt fish passes, 3D spatial structure, efficiency of fish passes, velocity water of flow

\section{INTRODUCTION}

As a result of developing structures crossing a river-bed, water ecosystems were divided into a series of sections. That contributed to the disturbance of the natural livingconditions for fish through disabling the migration, which remains a vital necessity for the ichthyofauna. Furthermore, many species of fish were cut-off from their historic habitats, spawning sites, feeding grounds, and shelters [Jungwirth et al., 1998; Lucas and Baras, 2001]. A reduction in the number of available habitats resulted in blocking the transfer and ex-change of genes within the fish population, and it therefore affected their quantity [Knaepkens et al., 2002; Knapen et al., 2003; Knaepkens et al., 2006]. In order to prevent that situation, water barrages were equipped with the facilities allowing for migration [Jungwirth et al., 1998; Clay, 2017; Cowxand Welcomme, 1998].

The constructed facilities have variable, uneven efficiency for various species of fish [Jungwirth et al., 1998; Stuart and Mallen-Cooper, 1999; Bunt et al., 2000]. The designs are developed based upon the requirements of one or selected groups of fish species. Most often, these are diadromous fish, mainly Salmonidae [Clay, 2017; Aarestrup et al., 2003; Gowans et al., 2003]. Unfortunately, such an approach makes a fish pass useless for the remaining species of ichthyofauna, i.e. for potamodromous fish [Puzdrowska, 2013].

The physical parameters of body and swimming abilities of potamodromous fish are often definitely smaller than in the case of diadromous fish, which are physically adapted to overcome huge migration barriers. Relatively small start 
velocities and shorter time of maintaining the velocities in the case of weaker specimens (it is also related to young specimens of Salmonidae) require provision of a possibility to quickly pass through the facility [Lucas and Baras, 2001; Clay, 2017].

It is known that fish use turbulences during the migration [Costa et al., 2019]. However, the impact of the turbulent flow on the biology of fish highly depends on the scale. The size and the orientation of whirls remain important components of habitats and fish behavior. The general range of circulation has a different effect for the swimming of fish with different body lengths. In order to understand the impact of turbulences on the efficiency of fish swimming, one shouldtake into account the size and the direction of a whirl in reference to fish. A turbulent flow does not adversely affect the ability of fish swimming, provided that the size of whirls does not exceed the size (length) of a fish body [Pavlov et al., 2000]. Lupandin [2005] provided additional details stating that the swimming ability decreases at a boundary whirl diameter, which is $66 \%$ of the fish's body length. Tritico and Cotel [2010] established that the loss of stability by fish occurs when the whirl's diameter reaches the values higher than $76 \%$ of the entire fish's body length. Then, the swimming abilities of fish decrease by $20 \%$. Another boundary size of a whirl -at which the swimming ability decreases and the swimming stability is lost-was reported by Liao and Cotel [2013], and it amounts to $50 \%$ of the fish's body length. The whirls having a size equal to or greater than the fish's body length cause rotation of their bodies and hamper keeping the position [Pavlov et al., 2000; Smithet al., 2014]. It was observed that fish are taken by the current toward the downstream station of the fish pass [Silva et al., 2012].

The whirl plane is also important. The whirls proper for migrating fish are placed within a horizontal plane, and they do not cause problems in swimming, as fish remain flexible within that dimension [Smith et al., 2014]. The whirls located in a vertical plane cause difficulties, because fish cannot bend vertically.

Turbulence is applied by fish in site conditions in order to reduce the locomotion cost. It was established that generation of whirls by fish during swimming, and subsequently control over them allow for a significant reduction of the energy cost borne by fish, and even its complete elimination [Ahlborn et al., 1991; Smith et al., 2014; Wilkes et al., 2017].
Representatives of ichthyofauna avoid the core of the stream of high velocity values in fish passes and bypass the zones of the stream flow with very high turbulence level, and the necessity of coming over them significantly increases the time necessary for passing through the following fishway's pool. Young fish spend the most of the time in the recirculation area having low flow velocities [Wang et al., 2010; Silva et al., 2012; Rodríguez et al., 2014]. This is why improving the efficiency of the fish pass is associated with a greater use of the zones of low flow velocity values and low turbulent kinetic energy (TKE) values by fish. Stationary fish swimming (also called cruising swimming) is possible in those areas of flow [Cornu et al., 2012]. In the case of the flow areas with extreme values of hydrodynamic parameters, the increased use of whirl structures in the movement of fish (drifting) is associated with a reduced physiological reaction and with a reduced frequency of their body movement [Costa et al., 2019].

It was identified that underfavorable conditions, i.e. at a proper size of a whirl and at relatively low values of Reynolds stress, fish may behave in two ways [Silva et al., 2012]. Most often fish continuously swim through the whirls. Their way of moving is characterized by a curvature of significant deviations from the route axis in comparison to the route of the fish within the main stream (area of high velocities). The other frequently occurring phenomenon is the fact that fish temporarily lose their spatial orientationduring the migration. They are usually able to correct the location of their bodies and regain stability, and find the way in short time. In order to regain stability, a fish must increase the hydraulic resistance of its body and limit its moves. It may only do that through pectoral fin spreading [Bioly and Magnan, 2002; Webb et al., 2010]. Studiesand site observations prove that some fish of the cyprinids species are not always able to regain the lost swimming orientation. As a consequence, they know how to move within the whirl curvature for a longer time while being somehow stuck inside.

In the case of fishways, the issue of shaping the spatial structure of flow was discussed in many studies, and those were most often referring to slot-type fishways [Rajaratnam et al., 1986; Katopodis, 1992; Marriner et al., 2016; Quaranta et al., 2016; Umeda et al., 2017]. Those have sometimes included additional deflectors [Cornu et al., 2012; Quaresma et al., 2018]. These strudiesdid not analyze the variability of flow structure at different levels of water within pools 
of fishways. The attempts of an extended spatial analysis for the flow structure may be found in the studies considering the pool-type fishways [Silva et al., 2012; Alexandre et al., 2013]. In the case of the slot-type fishways, the issue of spatial turbulent structure was addressed by Shamloo and Aknooni [2012] and Sanagiotto et al. [2019]. The studies included the impact of change of the bottom inclination or change of the geometry for the fishway pool on the flow structure [Wang et al., 2010; Tarrade et al., 2008; Chorda et al., 2010; Calluaud et al., 2014]. The analysis of height modification for the parapet in the main migration slot was presented by Pena et al. [2018], but the paper did not analyze the changes to the spatial flow structure. The importance of the knowledge on the spatial analysis of the flow structure on the example of bolt fishways was demonstrated by Puzdrowska and Heese [2019a].

Very interesting case of analysis of the flow structure and fish passage performance of a brush-type fishway is the research carried out by Kucukali et al. [2019]. On the flow in the (pool) basin no backflow forms in the middle of the basin and there is no rotational flow. Immediately behind the brush block, the mean flow velocity is reduced by $\sim 70 \%$, but the flow has not separated and no recirculation zone forms. This is a special feature of a fishway, different from other types of fish passes, resulting from permeable construction of a partition (brush blocks).

It should be emphasized that the spatial flow structures discussed in publications occur within the geometrical proportions of the examined facilities strictly determined only by the authors of publications. The smallest change may cause disturbance of hydraulics and therefore contribute to the changes of the spatial flow structure, which is important for the efficiency of the facility.

In summary, the analysis of publications proved that the spatial flow structure and velocities obtained within characteristic sections of the facility remain the more important elements affecting the efficiency of fish passes. This paper presents the results of the analyses performed for the spatial flow structure and for the distribution of water flow velocities remaining an effect of a small change to the geometry of the partition (arrangement of partitions). We have additionally extended the research by case tests, if an obstacle occurs in the facility at the fishway's partition. This paper focuses on the research for the new type of fish passes - bolt fishways.

\section{MATERIALS AND METHODS}

The description of the model and of the measurement method is similar in the case of this paper to the ones given in the studies, performed within the framework of our research series for bolt fishways [Puzdrowska and Heese, 2019a; Puzdrowska and Heese, 2019b]. The research was performed based upon 3 models; models A and $\mathrm{B}$ are laboratory models, and model $\mathrm{C}$ comprises site research. A prototype of the solution is model A, which reflects the basic assumptions for the construction. Model B remains a modification of model A, which includes moving of one bolt, and therefore the axis of partition for the main slot and for two smaller spillway slots. Model C is a fish pass constructed according to the concept given in model A at a weir in Rzeszów, at chainage km $63+760$ of the Wisłok River (in Poland).

\section{Description of the model}

The name of the structure (bolt fishway) is associated with the applied cross-barriers in the facility channel. These barriers are entirely different from the partitions of other technical fish passes. Cross-partitions are made of linearly placed cylindrical bolt elements of various heights, thus separating consecutive chambers (pools) of the fish pass. The cylinders are assembled on spindles and can be rotated. The cross-section of the bolt elements becomesnarrower with increasing height and allows for the formation of diverse flow conditions in the fish pass.

The basic assumptions on bolt fish pass geometry are as follows: channel width $4 \mathrm{~m}$, length of a single pool $-6 \mathrm{~m}$, long drop of the bottom $2 \%$. The designed actual flow was $2.14 \mathrm{~m}^{3} / \mathrm{s}$, at maximum filling of the pools to a height of $1.10 \mathrm{~m}$. Width of the main migration slot is $0.8 \mathrm{~m}$. On the other hand, the bolt elements have the following dimensions: (1) height of $1.3 \mathrm{~m}$; (2) height of $0.6 \mathrm{~m}$; (3) height of $0.8 \mathrm{~m}$. The cross-section of all elements is elliptic and has the following diameters: $0.64 \mathrm{~m}$ (semi-major axis) and $0.52 \mathrm{~m}$ (semi-minor axis). Bolt elements are assembled on steel spindles; this is why the bolt element may be rotated and therefore the hydraulic conditions in the facility may be regulated on the object's use stage.

Models A and B (Figure 1a and 1b) were developed in a linear scale of $1: 5$, for which the remaining parameters are as follows: width $0.8 \mathrm{~m}$, 
and length of a single pool $1.20 \mathrm{~m}$. The model was developed as a series of 8 pools. Drop of the bottom was $2 \%$. Maximum filling of the model pools was $22 \mathrm{~cm}$, and minimum one was $20 \mathrm{~cm}$. Thebolt elements had the following parameters: (1) height of $26 \mathrm{~cm}$; (2) height of $12 \mathrm{~cm}$; (3) height of $16 \mathrm{~cm}$. The cross dimension was reduced to $12.8 \mathrm{~cm}$ for the longer diameter, and to $10.4 \mathrm{~cm}$ for the shorter diameter. The measuring pool was placed in a central part of the model. The test flow corresponding with the flow probability criterion according to Froude scaling was $38 \mathrm{1} / \mathrm{s}$. For the purpose of the model, bolt elements were reproduced while keeping the scale. These elements were made of wet wood.

Model C (Figure 1c) is a fish pass constructed according to the concept given in model A with a slight modification of the bolt baffle. The structure is located at a weir in Rzeszów, at chainage $\mathrm{km} 63+760$ of the Wisłok River (in Poland). Due to the issues with insufficient volume of water in the facility (model C) it was decided that a $0.5 \mathrm{~m}$ wide slab should be embedded within the partition. The purpose of such a modification of the fishway was to keep proper filling for the facility, in accordance with the design assumptions.

It is an interesting case, which may be referred to closing the opening of slots at the application of the facility. Such an obstacle may be formed by e.g. tree branches transported by water, which narrow the flow in the fishway pool. That issue is often encountered in the facilities of that type, which was also observed in that particular fish pass in the case of upstream pools just after a year

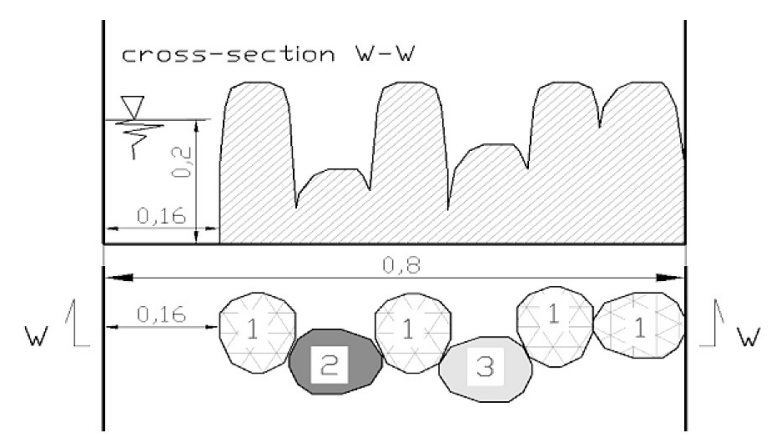

(a)

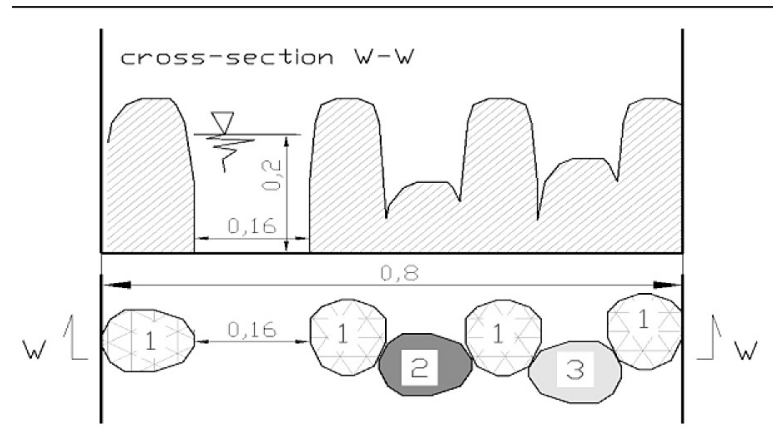

(b)

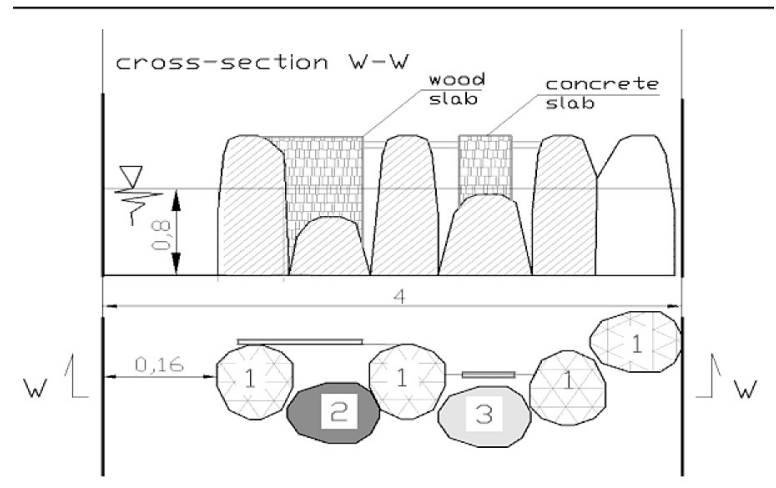

(c)

Figure 1. Schemes of partition for laboratory: (a) model A; (b) model B - dimensions given at the model scale (laboratory tests) [m]; (c) model $\mathrm{C}$ - dimensions given at the actual scale (field research)[m]. 
of facility operation. Test series $\mathrm{C}$ was conducted at an actual-scale object. The estimated flow at the object was about $1.6 \mathrm{~m}^{3} / \mathrm{s}$. An important aspect for that model is non-linear arrangement of bolt elements in the partition, which allows for the flow of water between particular elements of the bolt. Both openings over smaller bolts were blocked with slabs. A $0.5 \mathrm{~m}$ wide concrete slab was assembled over the higher bolt, whereas an additional plate was leaned against the outmost bolt element over the lower bolt (Figure 1c).

\section{Measurements}

Test series A and B were carried out at a laboratory model. For the purpose of testing, the three-dimensional acoustic Doppler Velocimeter SonTek 16-MHz MicroADV (Xylem Inc., Rye Brook, NY, USA) was applied. The frequency of the measurements was $25 \mathrm{~Hz}$. The length of the measurement at a single spot, measured using a probe, was established through preliminary tests for several spots located within the main flow and within the whirl area. From the collected data, it was established that the value of the second moment stabilizes quite early, and it usually is a series corresponding to a $90 \mathrm{~s}$ measurement. The spots located within the area of intensive whirls, where relative stabilization of the measurement was achieved after $300 \mathrm{~s}$ constitute exceptions. The average value of the velocity for the bolt section in the area of the main flow was stabilized after $180 \mathrm{~s}$ at most. For the whirl area underneath the bolt, regardless of the level of the spot, the minimum required measurement time was $300 \mathrm{~s}$. Therefore, $300 \mathrm{~s}$ was adopted as the minimum time for the performance of essential measurements. WinADV 32 software (version 2.012) was used as a filtration tool, and two types of filters were used: the acceleration method by Goring and Nikora [2002] (spike detection filter) and the minimum SNR (Signal-to-Noise Ratio) rate method (filter of minimum correlation rate). The minimum threshold value for the SNR rate should amount to 5 [Hawryło et al., 2011; Woś, 2016]. Both series produced a similar quantity of good data, which remained within $82-97 \%$.

Eleven sections were developed during the research (in the model's scale): section $\mathrm{r}-0.00 \mathrm{~m}$ (1) it is a bolt at the inlet to the measurement chamber; section $\mathrm{a}-0.15 \mathrm{~m}$ (2); section $\mathrm{b}-0.25 \mathrm{~m}$ (3); section $\mathrm{bb}-0.35 \mathrm{~m}(4)$; section $\mathrm{c}-0.50 \mathrm{~m}$ (5); section cc-0.65 m (6); section d $-0.85 \mathrm{~m}$ (7); section dd - $1.00 \mathrm{~m}(8)$; section ddd - $1.05 \mathrm{~m}$ (9); section ee $-1.10 \mathrm{~m}$ (10); section $\mathrm{rr}-1.20 \mathrm{~m}$ (11), as shown in the (Figure 2). During the research, 11 sections were developed, 18 measurement vertical lines each, as shown in (Figure 1) by Puzdrowska and Heese [2019b].

The measurements were performed in the sections for variable number of measurement levels. The number of levels resulted from a distance between the section and the inlet bolt and from its filling with water. Each time, the levels of water in sections were checked using a needle water gauge, and then further measurement levels were established, maximally every $2 \mathrm{~cm}$ - starting from the lowest one at the level of $1 \mathrm{~cm}$ over the bottom of the channel. The essential number of measurement levels - as results from the global grid for the pool -amounted to:

- for sections: $\mathrm{r}, \mathrm{a}, \mathrm{b}, \mathrm{bb}-10$ levels;

- for sections: c, cc- 11 levels;

- for sections: d, dd, ddd, ee, $r$ - 12 levels.

Additional spots were measured individually for each section below and over the level of spillway shelves in the inlet bolt partition (total of 4 additional measuring spots in each vertical line). In total the measurements were done for over 2000 spots in each of research variants.

Due to the fact that thedistance between the measurement cell and the probe's head was $5 \mathrm{~cm}$, there were huge difficulties in measuring final 3 spots placed at a level of $0 \mathrm{~cm}, 2 \mathrm{~cm}$, and $4 \mathrm{~cm}$ underneath the surface of water. Due to requirements of Matlab, which was used to develop the results, the authorshave decided to additionally measure those spots. The spots on a level of $4 \mathrm{~cm}$ underneath the surface of water $(16 \mathrm{~cm}$ above the bottom) were measured by placingthe probe at an angle. It was enabled by a rotary handle fixing the probe. Then, the flow was increased and measurement of the same spot was repeated; however, this time at the vertical alignment of the probe. After analyzing the results, it was established that the difference in values of average directional velocities and in their standard deviations is nomore than $3 \%$ of the value. Therefore, it was assumed that the geometry of the bolt affects the flow parameters more than the distance between the measurement spot and the surface of water. The spots placed at a depth of $0 \mathrm{~cm}$ and $2 \mathrm{~cm}$ below the water table at filling of up to $22 \mathrm{~cm}$ were additionally measured at the increased flow. It is important that the increase of flow (up to a 
height of $25 \mathrm{~cm}$ ) did not cause flooding of the bolt chamber (height of bolt elements is $26 \mathrm{~cm}$ ). This is why the stream flow character in the model was kept. An active opening in the bolt's section was not modified at the additionally measured spots, because those levels were placed above the highest parapet of additional spillway slots.

The presented research results (model Ai B) for bolt fishway were obtained as a consequence of laboratory tests performed on a physical model developed in the Technical University of Wroclaw.

Test series $\mathrm{C}$ was conducted at an actualscale object. RiverSurveyor S5 current profiler was applied for the research. The probe measures the vertical lines from the movable bottom up to the water-table. The height and the width of measurement cells depend on the speed of velocity changes in the section, and those are selected automatically.

For the measurements carried out in the flow area with low flow velocities (about $0.4 \mathrm{~m} / \mathrm{s}$ ) and water depths up to $1.5 \mathrm{~m}$, the system reports the data from $3 \mathrm{MHz}$ pulse coherent pings using a $2 \mathrm{~cm}$ cell size. In our research, such a measurement system was visible in the turbulence areas located behind the bolt baffle.

If the water depth is greater than $1.5 \mathrm{~m}$ or the water speed is greater than $0.4 \mathrm{~m} / \mathrm{s}$, the system shall use inconsistent pins with a frequency of $3 \mathrm{MHz}$ and a cell size optimised on the basis of the current water depth. The water depth in the chambers of the bolt pass during measurements was $0.85-0.95 \mathrm{~m}$, on average; thus, in the areas with flow speeds higher than $0.4 \mathrm{~m} / \mathrm{s}$, the system automatically registered the measurement for cells with a height of $0.1 \mathrm{~m}$.

The measurements during the field research were carried out in the sections placed in a distance: section $\mathrm{r}-0.00 \mathrm{~m}$ it is a bolt at the inlet to the measurement chamber; section a $-0.75 \mathrm{~m}$; section $\mathrm{b}-1.50 \mathrm{~m}$; section $\mathrm{bb}-2.25 \mathrm{~m}$; section $\mathrm{c}-3.00 \mathrm{~m}$; section $\mathrm{d}-4.50 \mathrm{~m}$; section ee $-5.80 \mathrm{~m}$; section $\mathrm{rr}-6.00 \mathrm{~m}$, as shown in the (Figure 2c). The measurements in each section were performed twice.

In order to ensure good quality measurement according to the probe instructions, attention should be paid to average signal amplitude and SNR. The signal amplitudes should be indicative of the bottom depth. This should approximate the Discharge Cutoff Depth (that condition was satisfied). The minimum SNR (signal-to-noise ratio) filtering settings for each cell for each beam for each sample were set at the level of $3 \mathrm{~dB}$, whichis the recommended minimum. The results of the research show that in the measurement cross-sections SNR was recorded in the range of $37.5-84.3 \mathrm{~dB}$.

\section{Methods of analysis}

Flow velocity analyses were performed using the following parameters:

- directional velocities averaged in time in a measurement spot, calculated for each of 3 directions of the stream flow $-\mathrm{x}, \mathrm{y}, \mathrm{z}$, respectively. A formula for calculation of the longitudinal velocity averaged in time in direction $\mathrm{x}$ is given below:

$$
v_{X}=\frac{1}{N} \sum_{i=1}^{N} v_{X i}
$$

Where $\mathrm{v}_{\mathrm{xi}}$ - are momentary longitudinal velocities recorded in a spot during laboratory tests, with the measurement frequency of $25 \mathrm{~Hz}$. The minimum measurement time was $300 \mathrm{~s}$.

- averaged flow velocity in the measurement spot:

$$
v=\sqrt{v_{x}^{2}+v_{y}^{2}+v_{z}^{2}}
$$

In the case of the laboratory model the scale coefficient for the flow speed was 2.25. In the case of this publication, the results were provided in an actual scale. The results were developed using the Matlab software.

\section{RESULTS}

\section{Three-dimensional flow structure}

\section{Model A}

In the case of the model described with measurement series A the following the structure of water flow may be seen (Figure 2a):

- area of the main flow within a route between the main slots (inlet to and outlet from the pool was marked with arrows determining flow directions); 
- main whirl area - between the zone of the main flow and the whirl area, there is no zone of free water mixing. The areas affect each other, but they are clearly separated. The separation of flow zones remains an effect of producing a water band surrounding the entire whirl area. The structure surrounding the whirl area is fed by water flowing down from additional slots in the bolt partition. The whirl area is feeding only two regions. The first one is located at the flow bottom over a length of $1-1.6 \mathrm{~m}$ and a width of 1.5-1.6 m (marked with a double blue curve having number I). Projection of the feeding area of flow and whirl structures for model A is shown in (Figure 3c) in the article [Puzdrowska and Heese, 2019a]. The stream flowing into the whirl area turns (at the channel bottom) and directly feeds structure no. 1 . In the area, where the first feeding zone occurs, the water band rises up quite rapidly. A stream feeding the whirl area from the main stream area flows through a window formed that way.

The surrounding structure has variable geometry parameters at a filling level. The basis has a smaller diameter. The diameter gradually increases along with the filling level. The other feeding area for the whirl zone (marked with a double blue curve with number IIa and IIb) is located in a distance of about 4.0-4.3 $\mathrm{m}$ from the inlet bolt, where a part of the stream is torn away from the surrounding structure at the bottom zone (on the left) and is routed in a direction opposite to the flow of the main stream in the fish pass. Over a width of $2.5-2.75 \mathrm{~m}$, the surrounding structure of water is rapidly lowered and hits the bottom. It is pressed to the bottom by an inclined structure of higher layers of the water band. Further on, over a width of $2.75-3.25 \mathrm{~m}$ the part of the stream from the surrounding structure in the bottom zone transforms into the first reverse (secondary) current occurring in the lower flow layers in fishway chamber (marked with a double blue curve having number IIa). Further on, over a width of 3.4-4 $\mathrm{m}$ and over a length of 3.5-4.3 $\mathrm{m}$ the higher layers of water of the surrounding structure hit the channel wall (marked with a double blue curve having number IIb). After the clash the stream is broken down and subsequently raised up, locally even to the level of $0.9 \mathrm{~m}$ over the bottom. A part of a stream is routed towards the migration outlet slot, and a part is routed just underneath the wall towards the whirl area (creating a second reverse current). Over a width of 3.9-4.05 m and over a length of 2.1-3.3 m the reverse current scrubs the external channel wall. After the second reverse current's stream deflects from the wall, both secondary (reverse) currents: from bottom and from wall, connect (collide) over a length of $1-1.5 \mathrm{~m}$ and over a width of 2.9-3.2 $\mathrm{m}$ and they are feeding smaller whirl structures (no. 1, 2, 3).

Smaller whirl structures placed within the whirl area are as follows:

- whirl no. 1 - located just underneath the partition, having counter-clockwise rotation. It is placed within a width of partially external spillway bolt with a lower shelf $(0.6 \mathrm{~m})$ and within the following huge bolt. It is a very stable vertical structure with regular crest into a level of the spillway shelf of the lower bolt. The base of the whirl is located over a width of $2 \mathrm{~m}$, its diameter is about $0.25 \mathrm{~m}$. Subsequently, the diameter quickly increasesalong with the rise of the measurement spot level, until it reaches the value of $1.25 \mathrm{~m}$ at the level of $0.6 \mathrm{~m}$;

- whirl no. 2 - located in the back part of the whirl area. That whirl somehow leans against the cross wall of the surrounding whirl. The structure is highly unstable and it is often dispersed into whirls of smaller diameter (which causes huge dispersion of the current line in that area). During the research an experiment comprising application of quartz sand proved that the whirl was formed again after each dispersion - cyclically. A slant whirl with counter-clockwise rotation is mainly located in the top part of the channel with unstable base placed at the wall of surrounding whirl at a level of about $1 / 3$ of pool filling. The most stable part of the structure is the crest disappearing at the surface. The maximum diameter of the crest is about $1 \mathrm{~m}$;

- whirl no. 3 - located on the opposite side to the main stream, just underneath the bolts and the external channel wall. The structure has a clockwise rotation. It is a very stable structure, vertical over almost the entire height, spillway $(0.8 \mathrm{~m})$ tilting towards the flow and simultaneously uplift under the transom baffle. The base of the whirl is placed over a length of $3.5-3.75 \mathrm{~m}$ in a distance of about $0.5 \mathrm{~m}$ from the bolt. Its diameter does not exceed $0.25 \mathrm{~m}$ in bottom zone and it quickly increases along with the rise of measurement spots level, until 


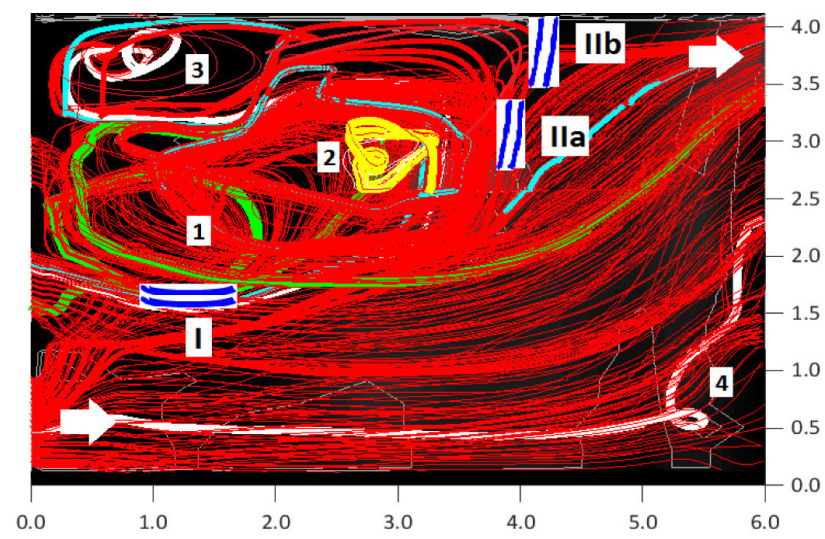

(a)

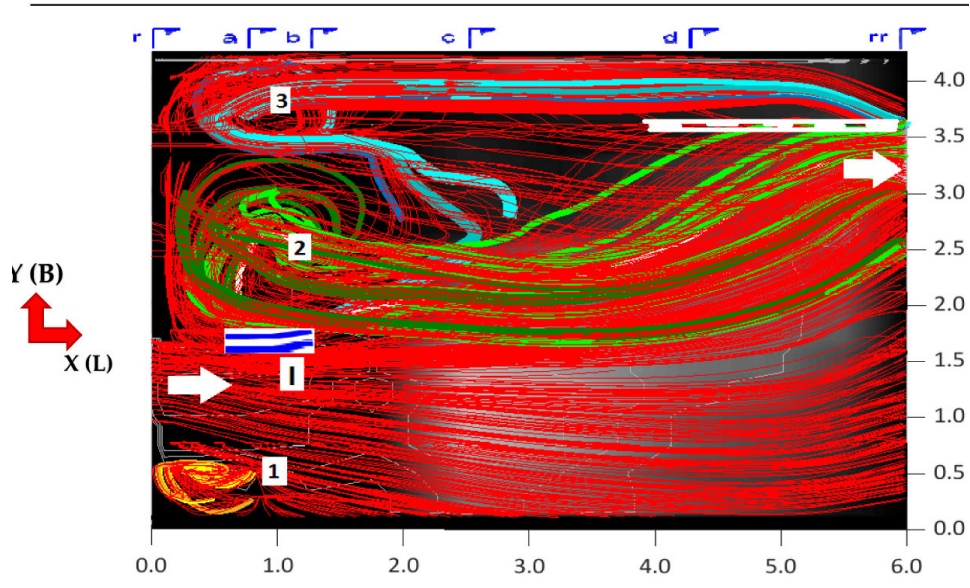

(b)

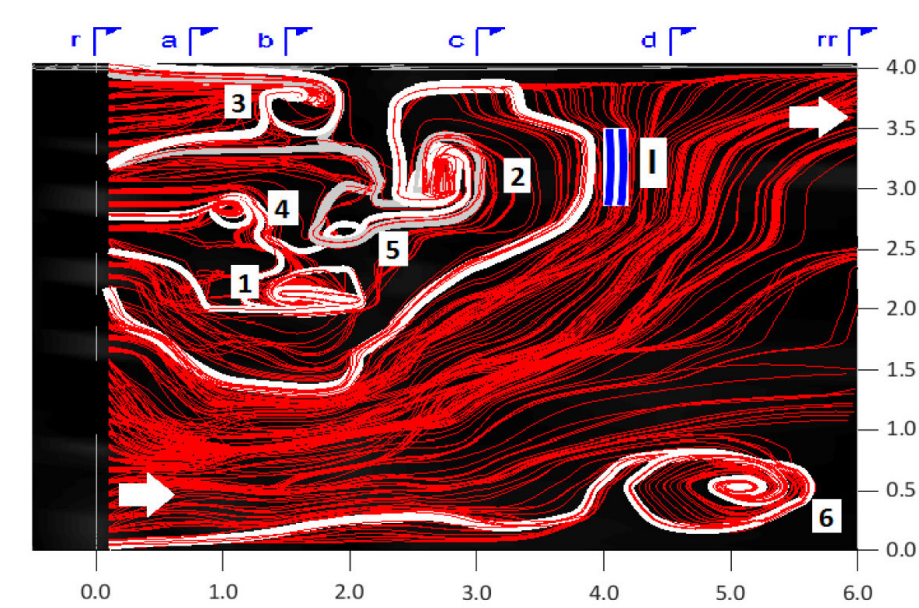

(c)

Figure 2. Projection (over chamber) of whirl structures in test pools: (a) model A; (b) model B; b) model C. Length of chambers in [m] was marked on axis X, width of chambers in [m] was marked on axis Y.

reaching - at the level of water-table - the level of about $1 \mathrm{~m}$ in cross-direction, and $2 \mathrm{~m}$ in longitudinal direction of the fish pass.

- additional whirl area - a small area generated just in front of the line of bottom bolts, opposite to the inlet slot. A part of the stream (on the right side) is torn away and routed against the essential direction of the stream flow in the fish pass. The separated mass of water forms a single slant whirl structure (no. 4), which does not have an unequivocally determined base. The whirl crest is placed diagonally over a width of $0-0.75 \mathrm{~m}$ and over a length of 5-6 $\mathrm{m}$ of the model the channel of the fishway. The whirl has a clockwise rotation. 
The afore-mentioned spatial flow structure is below an elevation of parapets for additional spillway slots. The impact of water spilling from shelves of lower bolts in the partition on the flow structure in model A is quite specific. The water flowing out from the smallest additional slot clashes with a part of the secondary stream feeding the whirl area. Theresultant stream formed that way breaks the whirl structures down, and forms a water wall on their crests (shown in Figure 3). The water of that structure is subsequently routed to the outlet partition in the top layer of flow (over an elevation of the smaller additional spillway shelf). In the case of model A, the stream flowing out from the largeradditional slot was almost pushed away towards the main stream, and it remains a main source feeding the structure surrounding the whirl area.

\section{Model B}

In the case of the model defined with a model series $\mathrm{B}$, the following the structure of water flow may be noted (Figure $2 b$ ):

- main flow area within a route between the main slots (inlet to and outlet from the pool was marked with arrows determining the direction of flow);

- main whirl area - separation of a part of the stream in the bottom zone $(0.05-0.25 \mathrm{~m}$ over the bottom; marked with a double blue curve withnumber I) may be seen in a distance of about $0.25-1 \mathrm{~m}$ from the inlet bolt, on the left side of the main stream flow route. It is a main feeding location for the entire whirl area. The system of structures in that model is significantly different than the model given in series A. Essentially, only 2 stable whirl structures (no. 2 and 3) are formed due to tearing the stream away. Furthermore, within a further section behind the area of main whirls, an area of intensive clash of flow streams was identified, and it is marked with a white dashed line.
Very intensive accumulation of rubble may be seen within that area. The features of the area whirl structures are as follows:

- whirl no. 2 - located just underneath a partition, having a counter-clockwise rotation. It is placed over a width of 3 bolts: external one, spillway with lower shelf, and the following huge bolt, i.e. over $1.5 \mathrm{~m}$. The length of the structure projection is $1.5 \mathrm{~m}$, on average. It is a very stable vertical structure with a crest disappearing just below the level of spillway shelf for the lower bolt $(0.6 \mathrm{~m})$. The whirl axis is located over a width of $2.5 \mathrm{~m}$ and over a length of $0.9 \mathrm{~m}$ of the pool. Its internal diameter is about $0.15 \mathrm{~m}$ at the bottom, but it quickly increases along with the rise of measurement spots up to the level of $0.6 \mathrm{~m}$;

- whirl no. 3 - located just underneath a partition, having clockwise rotation. It is placed over a width of 2 bolts: spillway with a higher shelf, and the last bolt in the partition. The whirl is limited with a neighboring channel wall. The whirl axis is located over a width of about $3.75 \mathrm{~m}$, in a distance of $0.75 \mathrm{~m}$ from the bolt. The whirl is not uniform. Current lines may be seen at the bottom, whichshows quite complicated arrangement of feeding for that structure. Water is transported to that whirl from the main stream, as well as directly from the whirl no. 2. Internal dimensions of the essential base if about $0.25 \mathrm{~m}$ of width and $0.5 \mathrm{~m}$ of length. One may see a specific tail of the whirl there, i.e. the structure is elongated towards the main flow in the bottom zone (up to $3.1-3.15 \mathrm{~m}$ of the pool length). It is a very stable vertical structure up to the level of bolt lower shelf $(0.6 \mathrm{~m})$. Disturbance of the structure occurs within a space limited with spillway shelves $-0.6 \mathrm{~m}$ and $0.8 \mathrm{~m}$. Moving away of the current line from the bolt and raising of water up may be noted - it is a consequence of the spilling water stream, but also of the part of water deflecting from the channel walls in

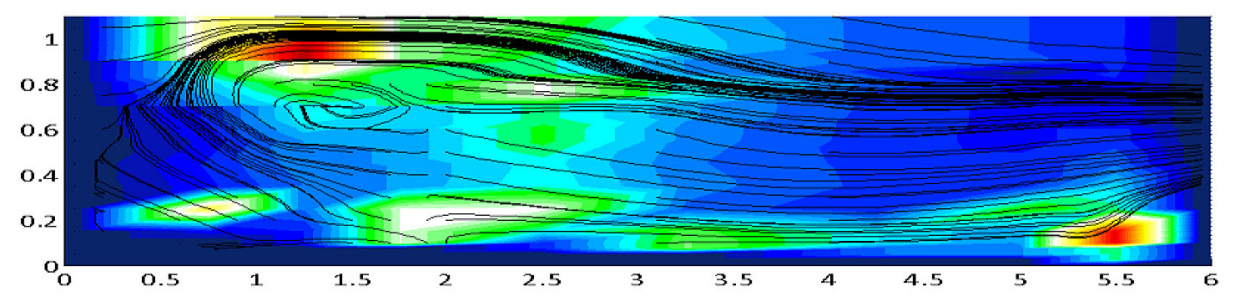

Figure 3. Projection of a dam of water, which is produced above the water of whirl No. 1 in model A [Puzdrowska and Heese, 2019a]. 
the fishway model. On a level of a higher shelf ( $0.8 \mathrm{~m}$ from the bottom) the whirl completely disappears, and the top layer is filled with a stream, which flows from the top to the bottom of the model.

- additional whirl area - a small area generated just underneath the bolt, on the right side of the main stream, due to tearing away a part of the stream. The whirl structure marked with number 1 is located within that area. The whirl has a clockwise rotation. It is a whirl placed within the vertical axis. The structure occurs within lower layers of water, from the bottom to the crest, and it fades away on a level of $0.5-0.6 \mathrm{~m}$ from the bottom. The maximum dimensions of the crest are $0.5 \mathrm{~m}$ of width and $0.75 \mathrm{~m}$ of length.

It was noted that both of the examined models were to a various degree vulnerable to the impact of water spilling from shelves of lower bolts in the partition on the flow structure. In the case of model B, the structures are yield to the influence of water and decompose with the formation of a grooved trough on the crown (like shown in Figure 4), or even break down (structure no. 3). The spilling water covers the entire spatial system of the flow.

\section{Model C}

In the case of the model defined with a model series $\mathrm{C}$, the following fields may be noted (Figure 2c):

- main flow area within a route between the main slots (inlet to and outlet from the pool was marked with black arrows determining the direction of flow);

- main whirl area - the whirl area of the Model $\mathrm{C}$ water feed is different from that of the models A and B. This variance results from the non-linear arrangement of the bolt elements in the partition. In the slots between the bolt elements, there is basic water feeding of the turbulence area. The area of turbulence is additionally supplied with the water from the main flow in a distance of about $4.0 \mathrm{~m}$ from the inlet bolt. Part of the stream (on the left) is separated and routed against the essential direction of the stream flow in the fish pass. The indicated area remains a place of additional feeding for the whirl area. A significant part of the area is occupied by large whirls $(1,2)$, and they are gathered inside of the greatest whirl surrounding the entire whirl area located underneath the line of bolts. Additional 3 whirls are present within the huge whirl structure, and they are fed only from the stream flowing between bolt elements in the partition (whirls no. 3, 4, 5).

The surrounding whirl has variable geometry parameters at the filling level. A base has a smaller diameter of about $3 \mathrm{~m}$. It gradually increases its value along with the level of filling. The whirl crest is located at the surface and it has a diameter of about $4.2 \mathrm{~m}$. The whirl surrounding the whirl area has a counter-clockwise rotation. The aforementioned smaller whirl structures are as follows:

- whirl no. 1 - located just underneath the partition, having a counter-clockwise rotation. It is placed over a width of partially external bolt and of the spillway with higher shelf $(0.8 \mathrm{~m})$, and the other further high bolt. It is a stable, but slant structure with a crest reaches the water surface. The base of the whirl is located in a distance of $0.5 \mathrm{~m}$ from the bolt. Its diameter amounts to about $0.1 \mathrm{~m}$, and it subsequently rises along with the increase of measurement spot level, until reaching the value of about $1.5 \mathrm{~m}$ at the crest level;

- whirl no. 2 - located in the back part of the whirl area. That whirl somehow leans against

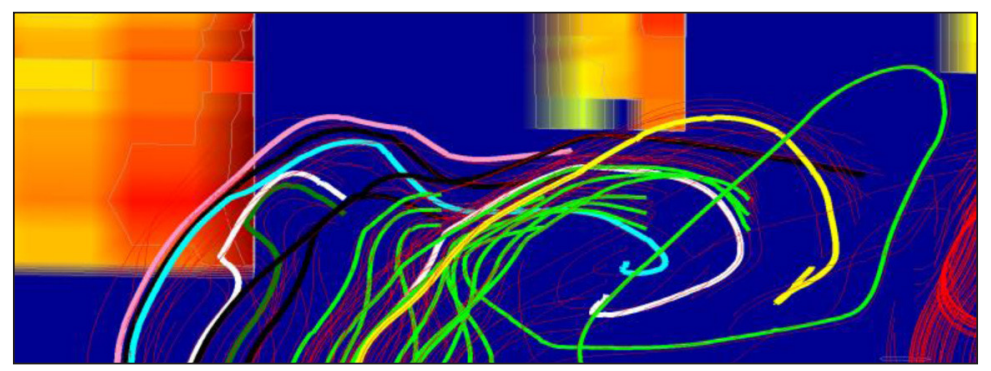

Figure 4. Breakdown of whirl No. 2 with a view of the grooved trough in model B [Puzdrowska and Heese, 2019a]. 
a slant wall of the surrounding whirl (as in the case of model A). The structure is stable. It is a vertical whirl with counter-clockwise rotation. The whirl extends from the bottom to the water surface. The maximum diameter of the crest is about $1.5 \mathrm{~m}$. The whirl is fed by two sources: the surrounding whirl, and whirl structure no. 5 ;

- whirl no. 3 - located underneath the partition, at the wall, having a clockwise rotation. The whirl is fed by waters flowing between concrete elements of the bolt. It is a stable vertical structure with a maximum diameter at the water surface, which is about $0.70 \mathrm{~m}$;

- whirl no. 4 - located just underneath the partition, having a clockwise rotation. It is a whirl with a maximum diameter (at the surface) of about $0.50 \mathrm{~m}$. The whirl is a slant structure. It is fed by water flowing from slots between the bolts;

- whirl no. 5 - located just underneath the partition, having a clockwise rotation. It is the smallest of all whirls, having the maximum diameter (at the surface) of about $0.3 \mathrm{~m}$. The whirl is partially fed with water from structure no. 4 , and partially by water from the partition slots directly. The structure is stable and vertical.

- additional whirl area - a small area generated just in front of the line of bottom bolts, opposite to the inlet slot, as in the case of model A. In model $\mathrm{C}$ the separated mass of water forms a huge single horizontal whirl structure (no. 6). The whirl crest is horizontal over a width of $0-0.8 \mathrm{~m}$ and over a length of 4.0-6.0 $\mathrm{m}$ of the fishway model channel. The whirl has a clockwise rotation.

\section{Velocity of water flow}

Different geometry of fishway partitions is absolutely reflected in the distribution method for velocity values (Figure5 and 6). A characteristic feature for models A and B is the impact of spillway shelf levels in smaller slots on the distribution of characteristics within entire sections.

It was established that in models A and B the sections located just underneath the bolt are noticeably stratified for velocity values. The further away the section is from the bolt, the impact gets gradually insulated, which means that the change of velocity values does not provide significant leaps. In the case of model $\mathrm{A}$, a distinct impact of spillway shelves is noticeable up to section d, which lies in a distance of $85 \mathrm{~cm}$ from the bolt ( $4.25 \mathrm{~m}$ in the actual scale). On the other hand, stabilization of value modification (without huge leaps) may be notified in the case of model $\mathrm{C}$ just in section c, which is $50 \mathrm{~cm}$ away from the bolt ( $2.50 \mathrm{~m}$ in the actual scale).

The impact of bolt spacing on the distribution of velocities within the main channel and within the entire area is demonstrated in this place by various routes of transfer for the main stream flow and by various locations of whirl zones with distinct flow whirl structures. One may also note a diverse concentration method for extreme values of directional velocities in the determined areas. The longitudinal value of velocity is the dominant component for both of the models.

In the case of research series $A$ distinct division into the area of the main flow and to the whirl area is highlighted. It was observed that in the case of model A, where the area of whirl generation is significantly greater, also the range of high longitudinal velocities is increased within the area of main flow. The highest values in the following sections provide the higher level of concentration. It results in lower velocities within the whirl area, while comparing to model B. Furthermore, model A also has higher velocity rates in the partition section and a higher area of their occurrence - both in the main slot, as well as in spillway slots. An analysis of the distribution of longitudinal velocities - averaged after some time - in model A, within the pool, proves the effect of water circulation zone range present underneath the bolt partition for the decrease (reduction) of the velocity value in the main stream. That effect is strongly reflected in a part of the stream bordering the whirl area (vertical lines no. 3 and 4), and is weaker for vertical line no. 2 located close to the channel wall. It is specific for that flow that after reaching the maximum value of velocity at the bottom part of the channel, the velocity is reduced to the elevation of spillway shelf. Then a peak of value is noted at the elevation of spillway shelf. The strongest one is on the level of $12 \mathrm{~cm}$ above the bottom ( $0.6 \mathrm{~m}$ in the actual scale), just underneath the line of spillway shelf for bolts of the larger slot (Figure 6).

It may also be noted that the greater the distance between the section and the bolt partition line is, the smaller the rate of velocity reduction would be. It is associated with reduction of the whirl area reach in following specific sections. 


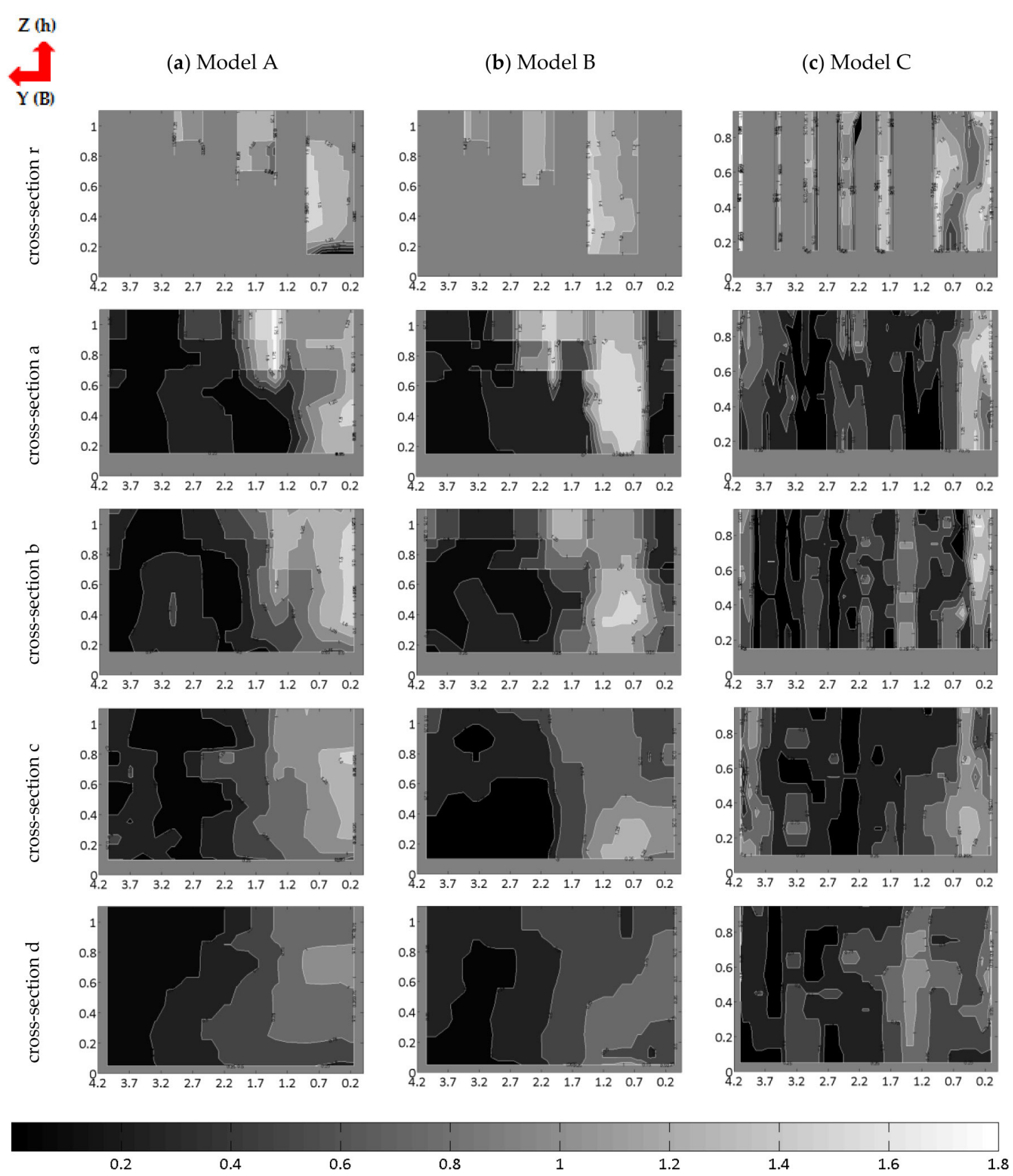

Figure 5. Summary of average flow velocities for 3 models: (a) model A; (b) model B; (c) model C. Water depth of chambers in [m] was marked on axis $\mathrm{Z}$, width of chambers in [m] was marked on axis Y. Velocities given at the actual scale $[\mathrm{m} / \mathrm{s}]$.

The discussed velocity characteristics prove huge synchronicity of occurrence levels in reference to the drop of the model bottom. The described reduction of velocity for the main stream in vicinity of the whirl zone corresponds with the increase of longitudinal velocity in the main stream within the area opposite to the whirl zone. Section c (Figure5) remains an area of high stream instability - impact of the inlet bolt may be seen there, but also the outline of impact of the bottom bolt at the outlet from the pool may also be noted. That impact manifests in proper levels of diagram course breakdown. The vulnerability of vertical lines to the bottom bolt depends on the location of measurement spot. In the case of a bolt partition (inlet) section for model A, a trend of changes to longitudinal velocity is different than in the case of the changes in the pool. Starting at the bottom, the curves prove logarithmic features, and that value is slightly reduced after reaching the maximum velocity - uniformly until reaching the level of lower shelf. Elevation of the spillway 
slot shelf is -contrary to the sections in the poola negative peak of the main stream velocity values. The area cut off with heights of spillway slot parapets in the bolt section is an area of gradual reduction of flow velocities; in turn, the final significant negative peak is the elevation of the higher spillway shelf. An analysis of distribution for horizontal and vertical velocities - averaged after some time - proved that they reach significantly smaller values than the longitudinal velocity, especially in case of the main stream flow area. In those areas, the longitudinal velocities area about 5 times higher, on average.

In the case of research series $B$ the area, where whirls form, is significantly smaller. The results prove a greater range of occurrence for the main flow; however, smaller concentration of high longitudinal velocities may be noted than in the case of model A. The longitudinal velocities with higher values are dispersed within a greater area of test section, but they are generally lower than in the case of the previous model. The area located just underneath the bolt, in front of the main slot (section a)is an exception. Opening of the slot is shaded with a very largearea of high velocities, which has not been identified in model A. However, model B also comprises lower velocity values in section of the partition. The distribution of values in the partition section is more even. There are no distinct back currents within the (a) Model A

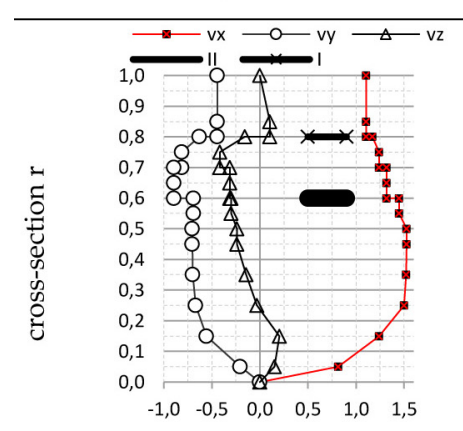

(b) Model B

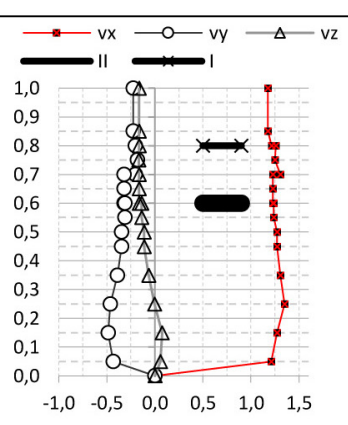

(c) Model C
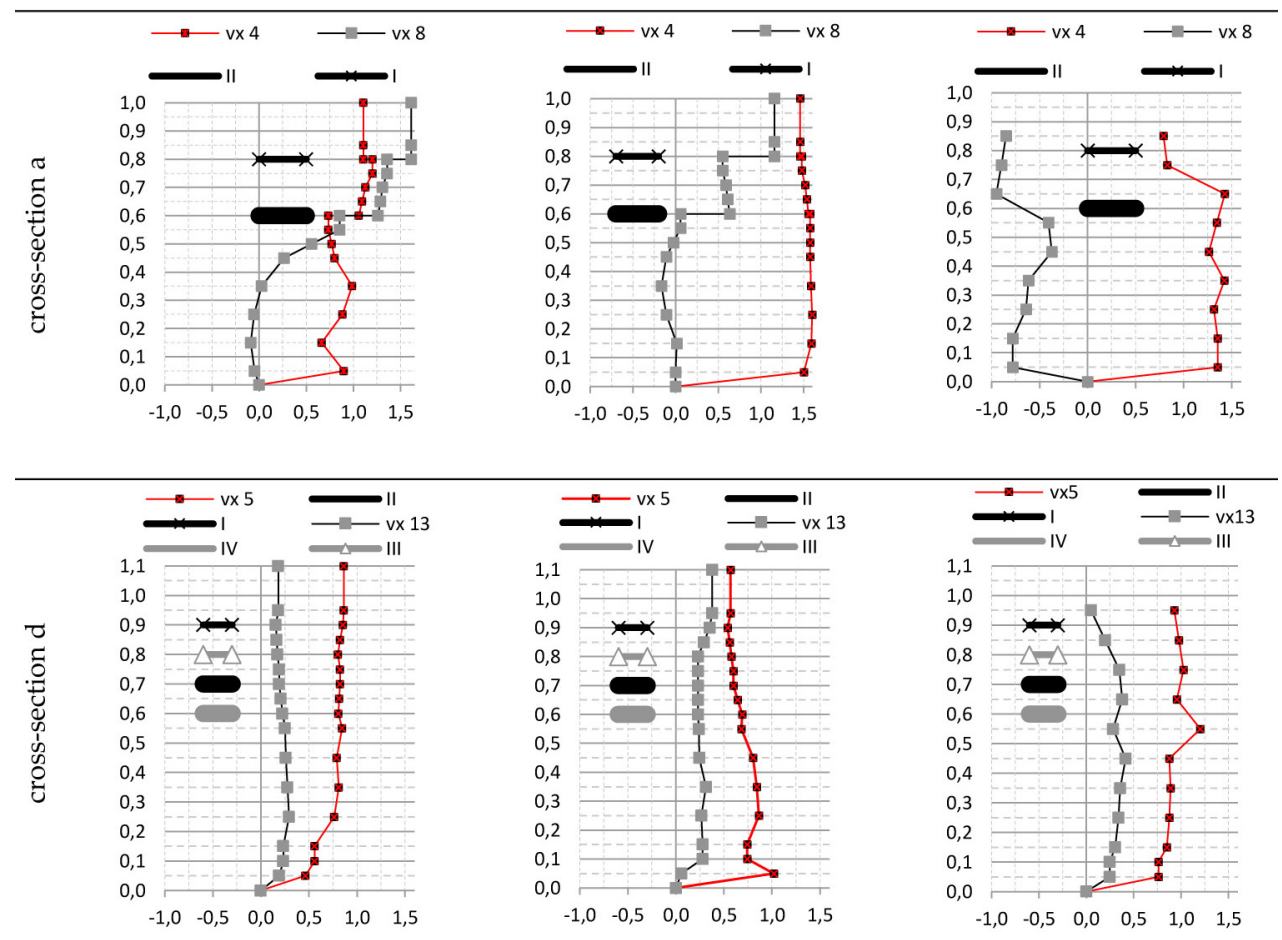

Figure 6. Vertical lines of directional velocities $[\mathrm{m} / \mathrm{s}]$ : (a) model A; (b) model B; (c) model C. Vertical lines in directions $\mathrm{x}, \mathrm{y}$, $\mathrm{z}$ were shown for bolt section (r). Vertical lines of longitudinal velocities (lines 4, 5 - main flow; lines 8,13 - whirl area) were shown for sections a and $\mathrm{d}$.

Markings: I - top shelf of the inlet bolt; II - bottom shelf of the inlet bolt; III - top shelf of the outlet bolt; IV - bottom shelf of the outlet bolt. 
pool over the spillway elevations; a flow compliant with the direction of the main stream prevails. The absence of distinct division into the area of main flow and the whirl area results from circulation of the separated stream part in the lower sections of hydraulic vertical lines, below spillway shelves of additional slots. Distribution analysis of longitudinal velocities - averaged after some time in model B, within the pool, proves much smaller effect of water circulation zone range present underneath the bolt partition for the decrease of the velocity value in the main stream. The reduced impact results from the reduced whirl area. Similarly as in the case of model A, in section of the main slot, over the elevation of lower spillway shelf, a negative peak of the longitudinal velocity value occurs. The further from the circulation zone it is, the lower - towards the channel bottom - the velocity levelling spot in measurement vertical lines would be. In the case of sections $\mathrm{c}$ and $\mathrm{d}$ of model B (Figure 5), where the impact of water circulation zones was strongly limited due to their small reach, the main stream was significantly dispersed. It resulted in a significant drop in the value of the highest velocities and also in narrowing of their occurrence area. They were mainly recorded at the bottom and up to the level of the parapet of the lowest spillway opposite to the section of the inlet bolt main slot. Furthermore, in the case of section d, significant stabilization and levelling of velocity rates in vertical lines may be noted. The strongest diversity of velocities between the main area and the whirl area occurs in model A. It results from the fact that the whirl area formed there occurs within the entire range of filling, which means that spatial whirl structures reach the surface zone. In the case of model B there is a strong longitudinal flow over the elevation of additional slot shelves, which contributes to increasing the average velocities in measurement vertical lines.

In the case of test series $\mathbf{C}$ the reach of occurrence for the whirl generation area is comparable to the area given in model A. However, that area covers significantly greater width than in the previous models, and it somehow overlaps the opening of the main slot in sections below the bolt. The area of high velocities is the smallest one among all of the models; however, one should take into account the fact that much smaller flow was examined than in the case of models $\mathrm{A}$ and $\mathrm{B}$. Therefore, the results may be ambiguous. Nonetheless, the distribution of velocities in the pool is important in this place. It demonstrates strong verticalization of values, which means that the values within vertical lines prove high trend of levelling the values. One cannot see horizontal stratification of velocity values in that place, which may result from the fact that the shelves were shaded with slabs (Figure 1c). Therefore, additional vertical slots were provided. As in the case of models A and B, velocity is reduced at the elevation of the bottom spillway shelf in the main slot; however, extreme velocities (maximum and minimum) are recorded below that elevation. The maximum velocity, the highest one for the entire vertical line, occurs in the middle of height if the smaller bolt. It is interesting that over the maximum rate the velocity is strongly reduced, until reaching the vertical line minimum. Then the velocity increases until it becomes reduced at the elevation of the bottom spillway shelf. Contrary to models $\mathrm{A}$ and $\mathrm{B}$, the velocity rate increases over the elevation of the bottom spillway shelf. The aforementioned reduction does not occur in sections downstream of the bolt, as it happened in the case of other models. The impact of shelves is clearly noticeable in section d. At the elevation of the bottom shelf for the pool outlet bolt one may notice a significant increase of longitudinal values. The remaining part of vertical lines comprises even values.

\section{DISCUSSION AND CONCLUSIONS}

This research presents deformation of flow spatial structure and of flow velocities distribution, which is caused by modification of geometry for the bolt partition (arrangement of slots).

On the basis of the research, one may assume that the number of slots in the partition and their location directly affect the quantity of circulation zones generated in the pool. However, the fact that one or more whirls are generated in each of the zones mainly depends on the geometry of slots and their location within the partition axis. The more whirls are produced in each of the whirl zones, the smaller their diameter would be. It is more favorable for fish migration.

The structure and the spatial distribution of velocities are to a much greater extent determined not by the flow size or by the fishway filling, but by geometry of spillway slots in the fish pass. Where relatively wide slots with a spillway shelf occur, the flow is strongly stratified and the 
produced whirl structures are wide at the crest and diversified in terms of diameter at the occurrence level. On the other hand, narrow vertical slots contribute to the provision of even diameters of whirls within entire vertical lines. It is important considering the fact that fish may efficiently pass through the fishway if the whirl diameter is smaller than $2 / 3$ of their body length [Lupandin, 2005]. Vertical slots contribute to uniforming the flow structure in vertical lines in terms of geometry. The size (diameter) of whirls obviously depends on the flow size and on the width of slot, but it seems that the lack of diversity in whirl sizes within vertical lines may adversely affect smaller fish. This observation may have a significant meaning to designing the fish passes for fish with diversified abilities to overcome obstacles.

Comparison of the results obtained by us with the tests performed by Kucukali et al. [2019] confirms huge significance of the geometry of additional overflow slots in the mechanism of water velocity distribution in the boltway.

The velocity profiles located just below the large overflow slot (cross section a, model A, profile vx 8), at depths from the bottom up to the elevation of the bottom parapet of the bigger spillway slot, behave exactly the opposite to those in the tested brush-type fishway. In model A, the large and small slots have a free (not covered) flowing zone.

In our research, the local maximum velocity is found just below the elevation of the bottom parapet of the bigger spillway slot. In the study of brush-type fishways, the maximum velocities are located in the bottom zone. This is probably related to the permeability of the partition (brush blocks). In these sections the correlation of velocity increment in the near-surface layer of water flow is visible. Kucukali et al. [2019] explains the increase in velocities in this area by the fact that the research was carried out on new, clean brush blocks.

Profile (vx 8) in cross-section a, model C, is located in the same place as model A measurement profile described above. The difference in the geometry of the bolt results from covering the overflow slots with vertical slabs and additionally from the elements being shifted in the axis of the partition, so that the slots reach to the bottom of the channel. This modification caused analogical velocity distributions with regard to the mechanism of velocity value changes, as in the case of research on brush-type fishway. It seems that this is strongly correlated with the fact that, despite the fact that flow-bristles disclose high elasticity and there are no constant distances between them, especially at height bristles, the fact that the flow of water takes areas in spaces between the flowbristles (on clean and new brushes), and thus in slots with a substantially elongated geometry in the vertical direction is responsible for the specific character of the velocity distribution. Similarly, we can speak about the properties of slots geometry in model $\mathrm{C}$ - where covering the slots with slabs allowed to obtain quasi-rectangular, bottom reaching slots, with dominating dimension in the vertical direction. It appears that this modification of the slots is directly responsible for the mechanism of velocity distribution, where local maximum velocities of the flow rates are observed at the bottom of the channel. Velocity distributions in our study and those in the study by Kucukali et al. [2019] differ in the near-surface flow layer. However, this can be explained by the fact that the slabs in our study were supported by horizontal beams, which apparently resulted in contraction in the flow under the beam and a change in coefficient of discharge. The influence of this effect is visible in the cross-section "a" below the bolt partition.

The research proved that the location of the main migration slot - and the partition construction or geometry - have much greater impact on the occurrence of high velocity areas than the other parameters. The more linear it becomes, the higher velocities underneath the bolt section would be, which blocks the ability of migration for weaker specimens (which was recorded in section a of model B). That conclusion may be confirmed by the research conducted by Puzdrowska [2013], where the flow parameters were examined in 2 other types of fishway (single-slot fishway and bolt fishway). The velocity rates and value of turbulent flow characteristics were much higher in the case of a single-slot fishway, where the arrangement of migration slots is linear. Therefore, the conclusion states that an alternant arrangement of main migration slots results in a significant dispersion in the fields of high velocities; thus, the maximum stream values are lower than in the case of the linear arrangement of the main route for the main flow.

In summary, the quantity of whirls generated in the fishway pool does not only depend on the number of spillway slots. It seems that the greatest impact on the flow structure is exerted by the 
arrangement of slots, whichmakes that element more important one for designing of fish passes. The size of whirls is determined by geometry of additional spillway slots.

The lack of additional spillway slots - except for the main migration slot - in the pool may effect in the occurrence of 1 huge whirl structure within the circulation area, as it is the case in single-slot constructions.

\section{Acknowledgements}

We would like to thank Envag in Warsaw for provision of a probe, i.e. RiverSurveyor S5 current profiler. The device was extremely useful for the site research. Professional and kind technical support provided by the company's staff is also worth noticing.

\section{REFERENCES}

1. Aarestrup, K., Lucas, M.C., Hansen, J.A. 2003. Efficiency of a nature-like bypass channel for sea trout (Salmo trutta) ascending a small Danish stream studied by PIT telemetry. Ecology of Freshwater Fish, 12, 160-168, https://doi. org/10.1034/j.1600-0633.2003.00028.x

2. Ahlborn, B., Harper, D.G., Blake, R.W., Ahlborn, D., Cam, M. 1991. Fish without footprints. Journal of Theoretical Biology, 148, 521-533, https://doi. org/10.1016/S0022-5193(05)80234-6

3. Alexandre, C.M., Quintella, B.R., Silva, A.T., Mateus, C.S., Romão, F., Branco, P., Ferreira, M.T., Almeida, P.R. 2013. Use of electromyogram telemetry to assess the behavior of the Iberian barbell (Luciobarbus bocagei Steindachner, 1864) in a pooltype fishway. Ecological Engineering, 51, 191-202, https://doi.org/10.1016/j.ecoleng.2012.12.047

4. Bioly, P., Magnan, P. 2002. Relationship between individual variation in morphological characters and swimming costs in brook char (Salvelinus fontinalis) and yellow perch (Perca flavescens). Journal of Experimental Biology, 205, 1031-1036, https:// www.ncbi.nlm.nih.gov/pubmed/ 11916998

5. Bunt, C.M., Cooke, S.J., McKinley, R.S. 2000. Assessment of the Dunnville fishway for passage of walleyes from Lake Erie to the Grand River. Ontario Journal of Great Lakes Research, 26, 482-488, https://doi.org/10.1016/S0380-1330(00)70709-X

6. Calluaud, D., Pineau. G., Texier, A., David, L. 2014. Estimation of the turbulent features of flow in vertical slot fishway: improvements on fish- way design criteria. In: 3rd IAHR Europe Congress, Book of Proceedings, Porto, Portugal. https:// www.researchgate.net/publication/281374883 Estimation_of_the turbulent_features_of the _flow in_vertical_slot_fishway_improvements_on_fishway_design_criteria

7. Clay, C.H. 2017. Design of Fishways and Other Fish Facilities. CRC Press, https://doi. org/10.1201\%2F9781315141046

8. Costa, M.J., Fuentes-Perez, J.F., Boavida, I., Tuhtan, J.A., Pinheiro, A.N. 2019. Fish under pressure: Examining behavioural responses of Iberian barbel under simulated hydropeaking with instream structures. PLOS ONE, 14(1), https://doi.org/10.1371/ journal.pone. 0211115

9. Cowx, I.G., Welcomme, R.L. 1998. Rehabilitation of rivers for fish. Fishing News Books, Oxford, U.K., Fishing News Books http://www.ecrr.org/ Portals/27/Rehabilitation_of_Rivers_for_Fish.pdf

10. Cornu, V., Baran, P., Damien, C., David, L. 2012. Effects of various configurations of vertical slot fishways on fish behaviour in an experimental flume. In 9th International Symposium on Ecohydraulics - ISE 2012, Vienna. http://oatao.univ-toulouse. fr/11268/

11. Chorda, J., Maubourguet, M.M., Roux, H., Larinier, M., Tarrade, L., David, L. 2010, Two-dimensional free surface flow numerical model for vertical slot fishways. Journal of Hydraulic Research, 48(2), 141151, https://doi.org/10.1080/00221681003703956

12. Goring, D.G., Nikora, V.I. 2002. Despiking Acoustic Doppler Velocimeter Data. Journal of hydraulic engineering, 128, 1, https://doi.org/10.1061/ (ASCE)0733-9429(2002)128:1(117)

13. Gowans, A.D., Armstrong, J.D., Priede, I.G., McKelvey, S. 2003. Movements of Atlantic salmon migrating upstream through a fish-pass complex in Scotland. Ecology of Freshwater Fish, 12(3), 177-189 https://doi.org/10.1034/j.1600-0633.2003.00018.x

14. Hawryło, A., Książek, L., Michalik A. 2011. Ocena warunków hydrodynamicznych sprzyjających bytowaniu ryb na odcinku rzeki Skawy. Acta Sci. Pol., Formatio Circumiectus, 10 (4), 5-16, http://www. formatiocircumiectus.actapol.net/pub/10_4_5.pdf

15. Jungwirth, M., Schmutz, S., Weiss, S. 1998. Fish migration and fish bypasses. Oxford [England]: Fishing News Books; Malden, MA: Distributor, USA, Blackwell Science.

16. Katopodis, C. 1992. Introduction to fishway design. Freshwater Institute Central and Arctic Region Department of Fisheries and Oceans, http://eem.wra. gov.tw/public/Attachment/41110254871.pdf

17. Knaepkens, G., Knapen, D., Bervoets, L., Hänfling, B., Verheyen, E., Eens, M. 2002. Genetic diversity and condition factor: a significant relationship in Flemish but not in German populations of the $\mathrm{Eu}-$ ropean bullhead (Cottus gobio L.). Heredity, 89, 280-287, https://doi.org/10.1038/sj.hdy.6800133 
18. Knaepkens, G., Baekelandt, K., Eens, M. 2006. Fish pass effectiveness for bullhead (Cottus gobio), perch (Perca fluviatilis) and roach ( $\mathrm{Ru}-$ tilus rutilus) in a regulated lowland river. Ecology of Freshwater Fish, 15, 20-29, https://doi. org/10.1111/j.1600-0633.2005.00117.x

19. Knapen, D., Knaepkens, G., Bervoets, L., Taylor, M.I., Eens, M., Verheyen, E. 2003. Conservation units based on mitochondrial and nuclear DNA variation among European bullhead populations (Cottus gobio) from Flanders (Belgium). Conservation Genetics, 4(2), 129-140, https://doi. org/10.1023/A:1023351025631

20. Kucukali, S., Verep, B., Alp, A., Turan, D., Mutlu, T., Kaya, C., Yıldırım, Y., Töreyin, B. U., Özelçi, D. 2019. Flow structure and fish passage performance of a brush-type fish way: a field study in the İyidere River, Turkey. Marine andFreshwater Research, -.https://doi.org/10.1071/MF18242;

21. Liao, J.C., Cotel, A. 2013. Effects of Turbulence on Fish Swimming in Aquaculture. In: Palstra A, Planas J (eds) Swimming Physiology of Fish, Springer, Berlin, Heidelberg, https://doi. org/10.1007/978-3-642-31049-2_5

22. Lucas, M., Baras, E. 2001. Migration of Freshwater Fishes, https://doi.org/10.1002/9780470999653

23. Lupandin, A.I. 2005. Effect of flow turbulence on swimming speed of fish. Biology Bulletin, 32, 461466, https://doi.org/10.1007/s10525-005-0125-z

24. Marriner, B.A., Baki, A.B.M., Zhu, D.Z., Cooke, S.J., Katopodis, C. 2016. The hydraulics of a vertical slot fishway: A case study on the multi-species Vianney-Legendre fishway in Quebec, Canada. Ecological Engineering, 90, 190-202, https://doi. org/10.1016/j.ecoleng.2016.01.032

25. Pavlov, D.S., Lupandin, A.I., Skorobogatov, M.A. 2000. The Effects of Flow Turbulence on the Behavior and Distribution of Fish. Journal of Ichthyology, 20, 232-261, https://scholarworks.umass.edu/ fishpassage_journal_articles/749/

26. Pena, L., Puertas, J., Bermúdez, M., Cea, L., Peña, E. 2018. Conversion of Vertical Slot Fishways to Deep Slot Fishways to Maintain Operation during Low Flows: Implications for Hydrodynamics. Sustainability, 10(7), 1-16, https://doi.org/10.3390/su10072406

27. Puzdrowska, M. 2013. Application of numerical methods in the design and analysis of fish pass efficiency. Technical Transactions Environment Engineering, 110, 99-109, http://yadda. icm.edu.pl/baztech/element/bwmeta1.element. baztech-137d6813-7994-4ccc-a683-18e4093f030

28. Puzdrowska, M., Heese, T. 2019a. Detailed Research on the Turbulent Kinetic Energy's Distribution in Fishways in Reference to the Bolt Fishway. Fluids 4, no. 2: 64, https://doi.org/10.3390/fluids4020064
29. Puzdrowska, M., Heese, T. 2019 b. Turbulent Kinetic Energy in Bolt Fishway. AgriEngineering 1, no. 2: 265-282, https://doi.org/10.3390/ agriengineering 1020020

30. Quaranta, E., Comoglio, C., Katopodis, C., Revelli, R. 2016. Numerical Simulations of flow field in vertical slot fishways. Conference: Atti del XXXV Convegno Nazionale di Idraulica e Costruzioni Idrauliche, Bolgona, 14-16 Settembre 2016, http:// hdl.handle.net/11583/2647665

31. Quaresma,A.L., Romão, F., Branco, P., Ferreira M.T., Pinheiro A.N. 2018. Multi slot versus single slot pooltype fishways: A modelling approach to compare hydrodynamics. Ecological Engineering, 122, 197206, https://doi.org/10.1016/j.ecoleng.2018.08.006

32. Rajaratnam, N., Van der Vinne, G., Katopodis, C. 1986. Hydraulics of vertical slot fishways. American Society of Civil Engineers, ASCE, 112, 909927, https://doi.org/10.1061/(ASCE)0733-9429(1 986)112:10(909)

33. Rodríguez, Á., Bermúdez, M., Rabuñal, J.R., Puertas, J. 2014. Fish tracking in vertical slot fishways using computer vision techniques. Journal of Hydroinformatics, 17, 275-292, IWA Publishing. https://doi.org/10.2166/hydro.2014.034

34. Sanagiotto, D.G., Rossi, J.B., Bravo, J.M. 2019. Applications of Computational Fluid Dynamics in The Design and Rehabilitation of Nonstandard Vertical Slot Fishways. Water, 11(2), 199, https://doi.org/10.3390/w11020199

35. Shamloo, H., Aknooni, S. 2012. 3D-Numerical Simulation of the Flow in Pool and Weir Fishways. In Proceedings of the XIX International Conference on Water Resources CMWR, 17-22 June 2012, Urbana-Champaign, IL, USA http:// cmwr2012.cee.illinois.edu/Papers/Special\%20Sessions/High-Dimensional $\% 20$ Computational $\% 20$ Modeling\%20of\%20Rivers\%20and\%20Streams/ Shamloo(Aknooni.Shadi).pdf

36. Silva, A.T., Katopodis, C., Santos, J.M., Ferreira, M.T., Pinheiro, A.N. 2012. Cyprinid swimming behaviour in response to turbulent flow. Ecological Engineering, 44, 314-328, https://doi.org/10.1016/j. ecoleng.2012.04.015

37. Smith, D.L., Goodwin, R.A., Nestler, J.M. 2014. Relating Turbulence and Fish Habitat: A New Approach for Management and Research. Reviews in Fisheries Science and Aquaculture, 22, 123-130, https://doi.org/10.1080/10641262.2013.803516

38. Stuart, I.G., Mallen-Cooper, M. 1999. An assessment of the effectiveness of a vertical- slot fishway for non-salmonid fish at a tidal barrier on a large tropical/subtropical river. Regulated Rivers: Research and Management, 15, 575-590, https://doi. org/10.1002/(SICI)1099-1646(199911/12)15:6<57 5::AID-RRR562>3.0.CO;2-Q 
39. Tarrade, L., Texier, A., David, L., Larinier, M. 2008. Topologies and measurements of turbulent flow in vertical slot fishways. Hydrobiologia, 609, 177188, https://doi.org/10.1007/s10750-008-9416-y

40. Tritico, H.M., Cotel, A.J. 2010. The effects of turbulent eddies on the stability and critical swimming speed of creek chub (Semotilus atromaculatus). Journal of Experimental Biology, 213, 2284-2293, https://doi.org/10.1242/jeb.041806

41. Umeda, C.Y.L., Lima, G., Janzen, J.G., Salla, M.R. 2017. One- and three-dimensional modeling of a vertical-slot fishway. Journal of Urban and Environmental Engineering, 11(1), 99-107, https://doi. org/10.4090/juee.2017.v11n1.099107

42. Wang, R.W., David, L., Larinier, M. 2010. Contribution of experimental fluid mechanics to the design of vertical slot fish passes. Knowledge and
Management of Aquatic Ecosystems, 02, EDP Sciences. https://doi.org/10.1051/kmae/2010002

43. Webb, P.W., Cotel, A.J. 2010. Turbulence: Does Vorticity Affect the Structure and Shape of Body and Fin Propulsors? Integrative and Comparative Biology, 50(6), 1155-1166, https://doi.org/10.1093/ icb/icq020

44. Wilkes, M. A., Enders, E. C., Silva, A. T., and Maddock, I. 2017. Position choice and swimming costs of juvenile Atlantic salmon Salmo salar in turbulent flow. Journal of Ecohydraulics 2(1), 16-27. doi:10 .1080/24705357.2017.1287532

45. Woś, A. 2016. The turbulence value in basic hydromorphological units of mountain river in example of Skawa river section. Infrastructure and ecology of rural areas, III/2, 935-947, http://dx.medra. org/10.14597/infraeco.2016.3.2.068 